\title{
Characterization of wine rennet and its kinetics by gel electrophoresis
}

\author{
T. M. Jiang and L. J. Chen ${ }^{1}$ \\ Technical Center, Beijing Sanyuan Foods Co. Ltd., Beijing 100085, P. R. China
}

\begin{abstract}
The rennet of glutinous rice wine (wine rennet) is an exclusive clotting agent for Chinese Royal cheese production. Some characterizations are reported herein in an attempt to provide evidence about the use of the protease as either a rennet substitute or an accelerator in cheese making and ripening. The results showed that wine rennet was a monomeric and unglycosylated protease. The N-sequencing indicated a high degree of similarity to other fungal rennets. The cleavage sites of wine rennet on oxidized insulin B chain identified by HPLC-mass spectrometry included $\mathrm{Gln}^{4}-\mathrm{His}^{5}$, $\mathrm{Ala}^{14}$ $\mathrm{Leu}^{15}$, Leu ${ }^{15}-\mathrm{Tyr}^{16}, \mathrm{Tyr}^{16}-\mathrm{Leu}^{17}$, and $\mathrm{Phe}^{24}-\mathrm{Phe}^{25}$ at $\mathrm{pH}$ 6.5, which were similar to those observed for Mucor rennet, but different from calf chymosin except for Leu ${ }^{15}$ $\mathrm{Tyr}^{16}$. A comparison study of the kinetic properties of wine rennet on bovine caseins with that of rennets from calf and Mucor miehei by gel electrophoresis showed that these rennets had similar coagulation efficiency but different reaction rates. Wine rennet exhibited a higher degree of degradation than the calf and Mucor enzymes at $\mathrm{pH} 6.5$ and $40^{\circ} \mathrm{C}$. Therefore, wine rennet would be an adjunct for calf rennet or an accelerator in cheese making.
\end{abstract}

Key words: wine rennet, characterization, kinetics, gel electrophoresis

\section{INTRODUCTION}

Cheese making is a long and expensive process; consequently, there is an economic impetus toward shortening the time required, particularly the duration of ripening. Hydrolysis of caseins is the most important proteolytic event during cheese production and is caused chiefly by rennet, indigenous milk enzymes, and microbial enzymes derived from starter and nonstarter bacteria (Azarnia et al., 2006). Calf rennet (chymosin) is considered the best milk-clotting enzyme for cheese

Received May 8, 2009.

Accepted November 27, 2009.

${ }^{1}$ Corresponding author: chlj@263.net manufacturers, but it possesses a relatively low proteolytic activity and is easily inactivated during the cooking and stretching of cheeses (such as Swiss and Mozzarella), resulting in a long ripening time. On the other hand, a worldwide shortage of chymosin has developed in recent years largely because of an increase in cheese production. Coagulants from other sources, such as plant and microbial coagulants, have been used as calf rennet substitutes to produce cheese in some countries (Poza et al., 2004). Enzyme preparations of fungal origin show a considerably greater degree of chemostability or higher proteolytic activity compared with calf chymosin, which is a disadvantage for the quality of final product. A mixture of purified fungal rennets may provide preparations that are superior to calf rennet with respect to faster ripening and flavor development (Garg and Johri, 1994).

Glutinous rice wine, the culture of glutinous rice with commercial starter (chiu-yao), contains a rennet-like enzyme and alcoholic flavor and has been used exclusively as a coagulant for Chinese Royal cheese. The rennetlike protease from glutinous rice wine, namely wine rennet, was isolated and purified, and its biochemical and substrate characterized (Jiang et al., 2006, 2007; Xue et al., 2008). However, few data exist regarding its use as a rennet substitute or as an accelerator; even the kinetic behavior on the substrate of $\kappa$-casein has not been established definitively. The aim of this study was to further describe its characteristics, including the $\mathrm{N}$-sequence, glycosylation state, specific cleavage sites on oxidized insulin B chain, and the kinetic parameters relative to the early action on bovine casein components.

Studies on dynamics of rennet toward natural caseins or synthetic peptides go back about 30 yr. Various methods, including HPLC, high-performance gel-permeation chromatography, automated ninhydrin, and spectrophotometry, have been developed to analyze hydrolysis (Visser et al., 1980; Carles and Martin, 1985; Carles and Ribadeau Dumas, 1985; Visser and Rollema, 1986; Vreeman et al., 1986). Ninhydrin and spectrophotometry are not direct assay methods for quantifying a specific hydrolysis fragment, whereas HPLC and highperformance gel-permeation chromatography require special equipment and sophisticated manipulation. As 
shown in Gaiaschi et al. (2000, 2001), SDS-PAGE may be a useful tool for quantitative analyze of the caseins and their fragments. In this work, urea-SDS/PAGE and densitometry were used to measure directly the kinetics of wine rennet on bovine casein components. In addition, we compared the dynamic behavior of rennets from Mucor miehei and calf under identical reaction conditions.

\section{MATERIALS AND METHODS}

\section{Enzyme Preparation}

Wine rennet, a purified freeze-dried powder from the laboratory of Technical Center of Beijing Sanyuan Foods Co. Ltd. (Beijing, China), was dissolved in $20 \mathrm{mM}$ sodium phosphate buffer, $\mathrm{pH}$ 6.5, to a concentration of $0.25 \mathrm{~g} / \mathrm{L}$, corresponding to $6.9 \mu M$ when the relative molecular mass $\left(\boldsymbol{M}_{r}\right)$ was taken to be $36,000 \mathrm{Da}$ (Jiang et al., 2007). Homogeneity of the enzyme preparation was examined by SDS-PAGE and N-terminal analysis. Chymosin and Mucor rennet from Mucor miehei were products of Sigma-Aldrich (St. Louis, MO) and were dissolved in the same buffer as wine rennet at a concentration of $5.95 \mu M$ for calf rennet $\left(M_{\mathrm{r}}\right.$ of $35,700 \mathrm{Da}$; Vreeman et al., 1986), and $5.4 \mu M$ for Mucor rennet $\left(M_{\mathrm{r}}\right.$ of 39,000 Da, according to the SDS-PAGE analysis).

\section{Substrate Solutions}

Oxidized insulin B chain (sequencing grade) and bovine casein components ( $\alpha_{\mathrm{S1}^{-}}, \beta-$, and $\kappa$-casein) were obtained from Sigma-Aldrich. The solution of insulin B chain $(0.5 \mathrm{mg} / \mathrm{mL})$ and casein components $(1.5 \mathrm{mmol} / \mathrm{L})$ were freshly prepared in $0.02 \mathrm{M}$ sodium phosphate buffer, $\mathrm{pH}$ 6.5. For kinetic measurements, concentrations of 6.8 to $341 \mu M$ k-casein $\left(M_{r}\right.$ of 19,000 $\mathrm{Da})$, and 3.6 to $181 \mu M \alpha_{\mathrm{S} 1}$-casein $\left(M_{r}\right.$ of $\left.25,000 \mathrm{Da}\right)$ and $\beta$-casein $\left(M_{r}\right.$ of $\left.24,000 \mathrm{Da}\right)$ were used. The protein concentrations of enzyme and substrate stock solutions were determined by using the micro-bicinchoninic acid method of Pierce Biochemicals (Rockford, IL) in which BSA (10 to $200 \mu \mathrm{g} / \mathrm{mL}$ ) served as the reference.

\section{N-Terminal Sequence Determination}

The enzyme purified by SDS-PAGE (stacking gel, $4 \%$ acrylamide; running gel, $12 \%$ acrylamide) was transferred to polyvinylidene fluoride (PVDF) membrane. The N-terminal sequence was determined at the Life Science department, University of Beijing (China). A search for similarity of sequence was performed using the Blast algorithm in the National Center for Biotechnology Information (NCBI) protein bank.

\section{Deglycosylation Analysis}

Deglycosylation of wine rennet was separately performed using peptide-N-glycosidase F (PNGase F) and $o$-glycosidase (Sigma-Aldrich) according to the manufacturer's instructions. For N-glycosylation analysis, 20 $\mu \mathrm{g}$ of purified wine rennet diluted in $20 \mu \mathrm{L}$ of twicedistilled $\mathrm{H}_{2} \mathrm{O}$ was boiled for $10 \mathrm{~min}$ in $1 \times$ glycoprotein denaturing buffer (0.5\% SDS, $1 \% \beta$-mercaptoethanol) to fully expose all glycosylation sites, and then incubated with 1 unit of PNGase $\mathrm{F}$ in $1 \times$ G7 reaction buffer (50 mmol/L sodium phosphate, $\mathrm{pH}$ 7.5) supplemented with $1 \%$ Nonidet $\mathrm{P}-40$ at $37^{\circ} \mathrm{C}$ for $2 \mathrm{~h}$. For the analysis of o-glycosylation, $100 \mu \mathrm{g}$ of purified wine rennet was diluted in $13 \mu \mathrm{L}$ of deionized water and mixed with 4 $\mu \mathrm{L}$ of $5 \times$ reaction buffer $(250 \mathrm{~m} M$ sodium phosphate, $\mathrm{pH}$ 5.0). After the mixture was incubated at $37^{\circ} \mathrm{C}$ for $1 \mathrm{~h}, 2 \mu \mathrm{L}$ of $o$-glycosidase was added and incubated at $37^{\circ} \mathrm{C}$ for 1 to $3 \mathrm{~h}$. The untreated and treated wine rennets were analyzed by $12 \%$ SDS-PAGE.

\section{Cleavage Specificities Toward Oxidized Insulin B Chain}

Hydrolysis of Insulin B Chain. One microgram of each enzyme was added to $100-\mu \mathrm{L}$ solutions of oxidized insulin B chain $(0.5 \mathrm{mg} / \mathrm{mL})$ prepared in the previous step. The mixtures were incubated at $37^{\circ} \mathrm{C}$ for $3 \mathrm{~h}$ at $\mathrm{pH}$ 6.5. Then, 1 drop of concentrated $\mathrm{NH}_{4} \mathrm{OH}$ was added to inactivate the enzyme. To prepare the samples for HPLC-MS analysis, the hydrolysate was filtered through $0.22-\mu \mathrm{m}$ filters.

HPLC-MS Analysis. The untreated insulin B chain and the rennet-treated products were analyzed by HPLC on an Agilent 1100 system (Agilent Technologies, Santa Clara, CA) with a diode array detector using a Zorbax Eclipse XDB-C18 reverse phase column

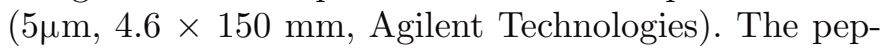
tides were eluted with a linear gradient of acetonitrile $(5-40 \%$ in $40 \mathrm{~min})$ in $0.1 \%$ formic acid at a flow rate of $0.8 \mathrm{~mL} / \mathrm{min}$. The effluents were monitored by measuring the absorbance at $215 \mathrm{~nm}$ and directly subjected to molecular mass determination using a HPLC-coupled Esquire 6000 ion trap mass spectrometer (Bruker, Bremen, Germany) operating in the positive electrospray mode, with a potential of $4 \mathrm{kV}$ applied to the electrospray needle. Full scanning analysis was performed in the range of 50 to $3,000 \mathrm{~m} / z$. The HPLC-MS spectra were analyzed by using the Biotools software (Bruker) for comparison with the variations.

\section{Determination of the Kinetic Parameters}

Enzyme-Casein Reaction. Caseins were digested with rennet $(50: 1, \mathrm{vol} / \mathrm{vol})$ at $40^{\circ} \mathrm{C}$ for $120 \mathrm{~s}$, and the 
Table 1. The N-terminal amino acid sequence determination of wine rennet and the NCBI Blast search results

\begin{tabular}{lllc}
\hline & Source & Compared sequence & $\begin{array}{c}\text { Homology }^{1} \\
(\%)\end{array}$ \\
\hline Protein & Chiu-yao (commercial starter) & ${ }^{1}$ GTGSVPVTDYE/QNDVE $^{15}$ & - \\
Wine rennet & ${ }^{69}$ GTGSVPVTDYYNDIE $^{83}$ & 86 \\
Rhizopuspepsin-2 precursor & Rhizopus niveus & ${ }^{2}$ GVGTVPMTDYGNDVE $^{16}$ & 73 \\
Rhizopuspepsin-2 & Rhizopus chinensis & ${ }^{1}$ GTGTVPVDDGNDIE $^{15}$ & 73 \\
Mucor rennet & Mucor bacilliformis & ${ }^{71}$ GSVDTPGLYDFLEE $^{85}$ & 20 \\
Mucor rennet & Mucor pusillus & ${ }^{60}$ EVASVPLTNYLDSQY $^{73}$ & 40 \\
Calf chymosin & Bos taurus & ${ }^{90}$ STGSATTTPIDSLDDA $^{105}$ & 33 \\
Endothiapepsin & Cryphonectria parasitica & \\
\hline
\end{tabular}

${ }^{1}$ Comparison with sequences in National Center for Biotechnology Information database.

reactions were stopped immediately by mixing (1:1, $\mathrm{vol} / \mathrm{vol})$ with sample buffer containing mercaptoethanol $(0.2 M)$ and urea $(8.0 M)$. Duplicates were prepared and examined for each substrate concentration.

Electrophoresis Analysis. The kinetic behavior of wine rennet on different casein components was analyzed by the modified urea-PAGE method of Andrews (1983), which was performed with $16.5 \%$ acrylamide gels (Sigma) and $0.1 \%$ SDS using a Mini-Protean Tetra electrophoresis system (Bio-Rad Laboratories, Hercules, CA). The peptides formed during the enzyme reaction were quantified with a gel scanner and the Image Master 1D software (ver. 4.0; Tanon GIS 2010, Shanghai Tanon Science \& Technology Co. Ltd., Shanghai, China). To calculate the amount of caseinderived fragments in each sample, a calibration curve was generated by plotting the known value of caseins loaded onto the gel versus the corresponding average density of pixels across the band length and integrating over the band width with Image Master software and assuming that the fragments had approximately the

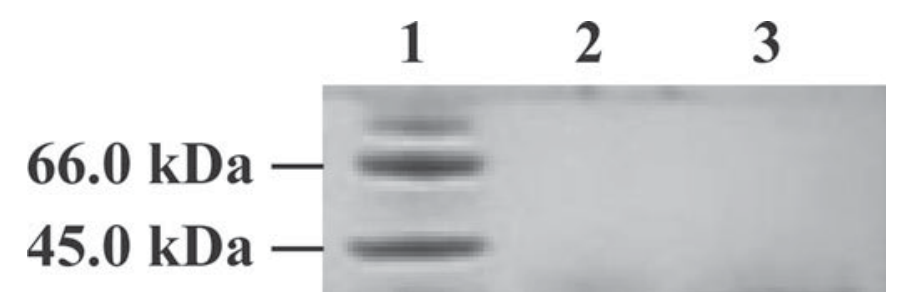

\section{$31.0 \mathrm{kDa}$}

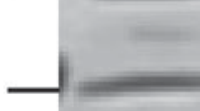

\section{$14.4 \mathrm{kDa}$}
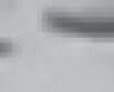

Figure 1. Homogeneity of wine rennet examined by SDS-PAGE $(15 \%)$. Lane $1=$ protein molecular weight markers; lane $2=$ native enzyme; lane $3=$ denatured enzyme. same affinity for Coomassie Blue. Every sample was analyzed at least 3 times, and the coefficient of variation was always $<5 \%$.

Calculation of Kinetic Parameters. The initial velocity of the enzyme reaction was calculated using the amount of casein-derived fragments quantified by gel analyses with time. Initial rates $(\boldsymbol{v})$ and substrate concentrations $([\mathbf{S}])$ were used to construct LineweaverBurk plots of $1 / v$ against $1 /[\mathrm{S}]$. From the linear plots, the kinetic parameters Michaelis constant $\left(\boldsymbol{K}_{\mathrm{m}}\right)$, catalytic turnover number $\left(\boldsymbol{\kappa}_{\text {cat }}\right)$, and proteolytic coefficient $\left(\boldsymbol{\kappa}_{\text {cat }} / \boldsymbol{K}_{\mathrm{m}}\right)$ were calculated.

\section{RESULTS AND DISCUSSION}

\section{N-Terminal Sequence and Sequence Alignment}

The homogeneity of wine rennet determined by SDSPAGE under denaturing and native conditions showed that it was a single polypeptide chain and in a molecular monomeric state because it migrated as a single band at the same rate (Figure 1). The N-terminal sequencing confirmed that the polypeptide comprised 15 amino acids, as shown in Table 1.

The microorganisms involved in the fermentation of glutinous rice were isolated and identified, and included mainly mold, yeast, and bacterium; the milk-clotting enzyme may be produced by the mold (Liu et al., 2001; Teng, 2005). Results of sequence analysis by the NCBI Blast algorithm showed that the N-terminal peptide sequence of the wine rennet conformed to that of the rhizopuspepsin from Rhizopus fungus, and the homology was 86 and $73 \%$ with Rhizopus niveus (direct submission) and Rhizopus chinensis (Takahashi, 1988), respectively (Table 1 ). Sequence identities with calf chymosin (Hidaka et al., 1986), Mucor rennin from Mucor pusillus (direct submission), and endothiapepsin from Cryphonectria parasitica (Barkholt, 1987) were $<40 \%$. However, the percentage of sequence identity between wine rennet and Mucor bacilliformis protease, a potentially better substitute of the calf rennet (Machalinski et al., 2006), was up to $73 \%$. This finding confirmed that the wine rennet was produced from the mold strain. 


\section{1 \\ 2 \\ 3}

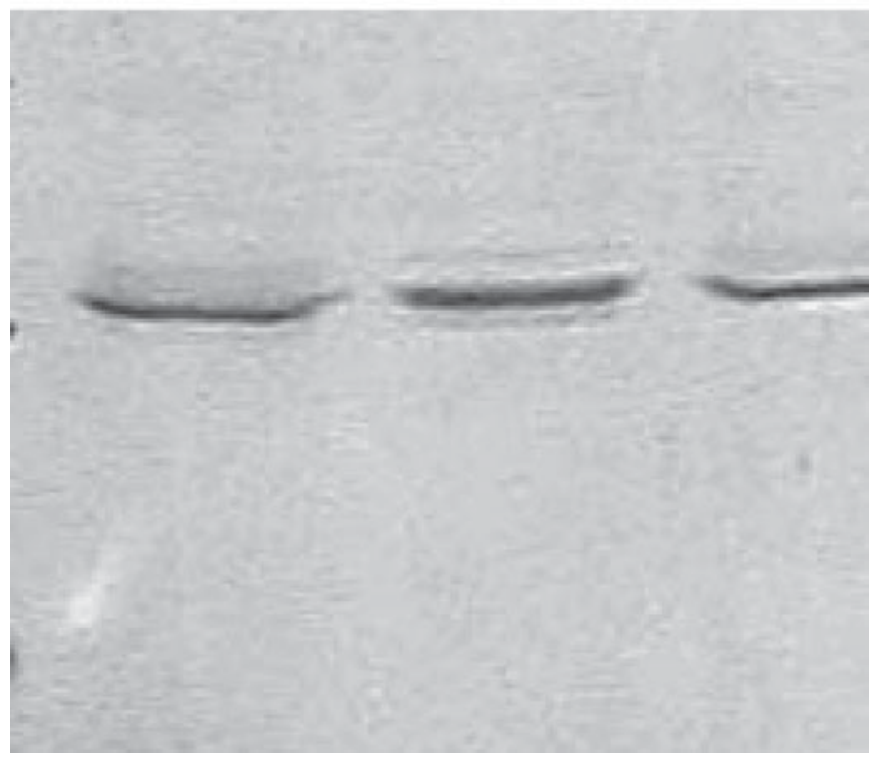

Figure 2. Deglycosylation test of wine rennet. Lane $1=$ untreated rennet; lane $2=$ treated with peptide- $\mathrm{N}$-glycosidase $\mathrm{F}$; lane $3=$ treated with $o$-glycosidase.

\section{Glycosylation Analysis}

It has been reported that the amino acid sequence of Mucor rennet contains possible $\mathrm{N}$-glycosylation sites, and the enzyme from $M$. miehei has a high carbohydrate content (Rickert and McBride-Warren, 1974; Aikawa et al., 1990). In contrast, rennets such as rhizopuspepsin from $R$. niveus are not glycosylated as is the case for bovine chymosin (Costa et al., 1997). The glycosylation state of wine rennet was determined with PNGase F ( $N$ glycosylation) and o-glycosidase (o-glycosylation), and results are shown in Figure 2. No changes in molecular weight between the digested and undigested rennet suggest that this protease is not glycosylated during the fermentation of commercial starter. We also confirmed that wine rennet is a member of the rhizopuspepsin group.

The importance of glycosylation is not well known in the aspartyl-protease family. Aikawa et al. (1990) found that, besides the effect on secretion from cells, glycosylation caused distinct modulation of the enzyme properties including milk-clotting and proteolytic activities, resulting in a lower ratio of clotting activity and proteolytic activity, which was disadvantageous for cheese-making. It has been proposed that glycosylation leads to higher thermostability by stabilizing molecular conformation (Costa et al., 1997), and thus cannot be inactivated at normal pasteurization temperatures,
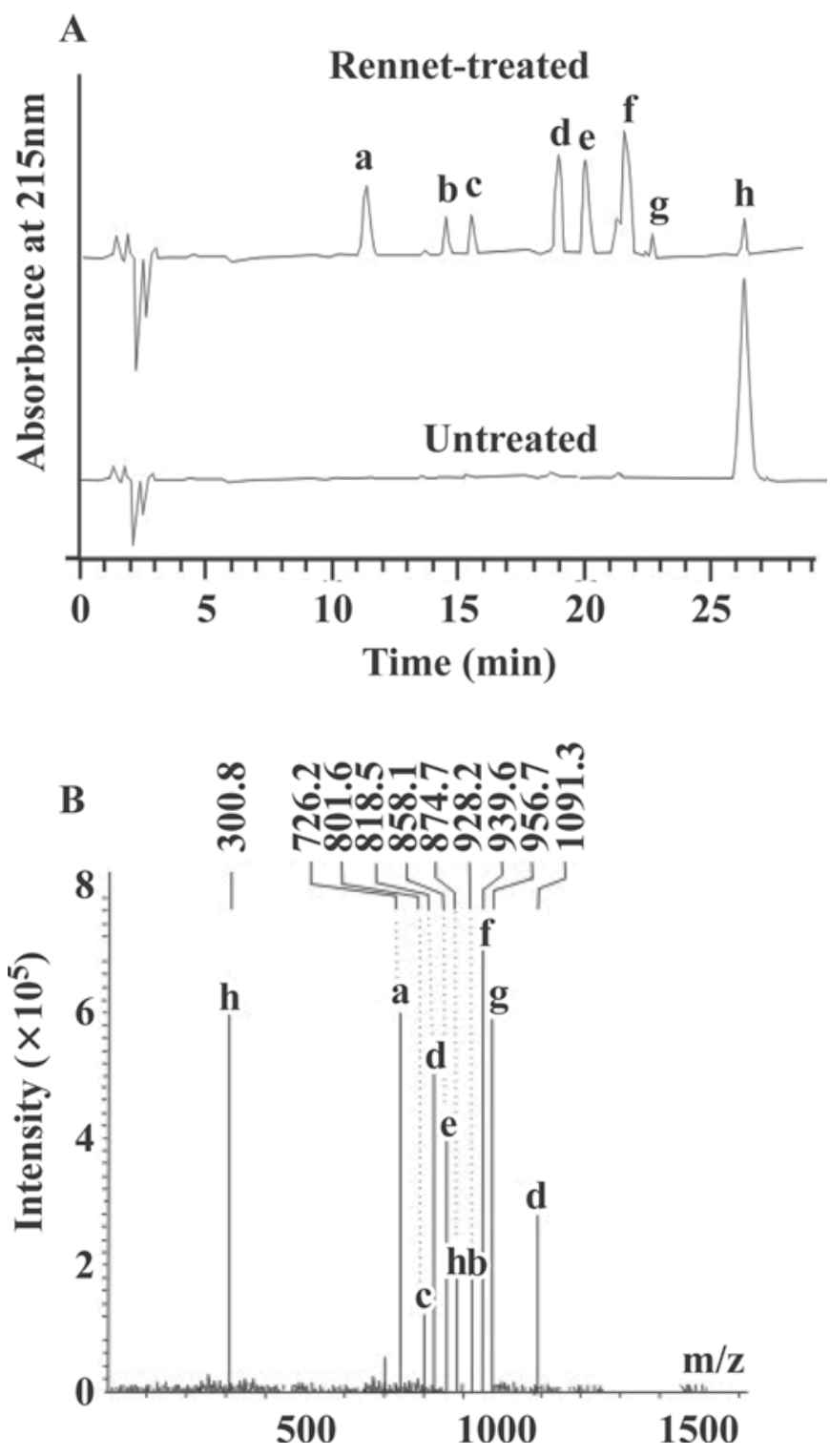

Figure 3. Analysis of wine protease digest from oxidized insulin B chain by HPLC-mass spectrometry; A) HPLC analysis, where a to $\mathrm{h}$ indicate HPLC fractions; B) mass spectrometry analysis.

which leads to problems in processing of cheese whey (Garg and Johri, 1994). The deglycosylation analysis suggests that wine rennet may be superior to Mucor rennet as a chymosin substitute.

\section{Identification of Specificity Sites}

According to Garg and Johri (1994), rennets hydrolyze peptide bonds flanked by bulky hydrophobic amino acids, and calf chymosin, Mucor rennin, and endothiapepsin from C. parasitica preferentially split aromatic and hydrophobic amino acid as evidenced by bond specificity on the oxidized insulin B chain. To 


$\begin{array}{lccccc} & { }^{1} \text { F-V-N-Q- } H^{5}-\mathrm{L}-\mathrm{C}^{*}-\mathrm{G}-\mathrm{S}-\mathrm{H}^{10}-\mathrm{L}-\mathrm{V}-\mathrm{E}-\mathrm{A}-\mathrm{L}^{15}-\mathrm{Y}-\mathrm{L}-\mathrm{V}-\mathrm{C}^{*}-\mathrm{G}^{20}-\mathrm{E}-\mathrm{R}-\mathrm{G}-\mathrm{F}-\mathrm{F}^{25}-\mathrm{Y}-\mathrm{T}-\mathrm{P}-\mathrm{K}-\mathrm{A}^{30} \\ \text { Wine } & \uparrow & \uparrow & \uparrow & \uparrow & \uparrow \\ \text { Calf } & & \uparrow & \uparrow & \uparrow & \uparrow \\ \text { Mucor } & \uparrow & \uparrow & \uparrow & \uparrow & \uparrow \\ \text { Rhizopus } & \uparrow & \uparrow & \uparrow & \uparrow & \uparrow\end{array}$

Figure 4. Summary of the specificity of the rennet-like protease from rice wine and compared with other sources on the oxidized insulin B chain at $\mathrm{pH} 6.5$ and $37^{\circ} \mathrm{C}$. Wine $=$ the rennet-like enzyme from glutinous rice wine; Calf $=$ calf chymosin; Mucor $=$ aspartic protease from $M u c o r$ miehei; Rhizopus = aspartic protease from Rhizopus chinensis (Athaudaa and Takahashia, 2002).

determine the cleavage specificity of wine rennet, the product of enzyme-digested insulin B chain was analyzed by HPLC-MS (Figure 3). Seven fractions were separated on HPLC (Figure 3A), each of which was further identified from its molecular mass scanning by MS (Figure 3B). The fragments $\mathrm{a}, \mathrm{b}, \mathrm{c}$, and $\mathrm{g}$ in Figure 2A corresponded to peptides $\mathrm{Phe}^{25}-\mathrm{Ala}^{30}$ (725.7 Da), Leu ${ }^{17}-\mathrm{Phe}^{24}$ (928.01 Da), His ${ }^{5}-\mathrm{Leu}^{15}$ (1,602.3 Da), $\mathrm{Phe}^{1}-\mathrm{Leu}^{15}$ (1,715.3 Da), Phe ${ }^{1}-\mathrm{Tyr}^{16}$ (1,877.2 Da), and Leu $^{15}$-Ala ${ }^{30}(1,911.4$ Da), respectively (Figure 3B). For fraction $\mathrm{d}$, peptide mapping indicated that it was a mixture of fragments $\mathrm{Leu}^{17}-\mathrm{Ala}^{30}(1,634.6 \mathrm{Da})$ and Tyr $^{16}-\mathrm{Phe}^{24}(1,043.1 \mathrm{Da})$, because the molecular mass calculated from the amino acid sequence was consistent with the observed mass, 818.5 Da $\left([\mathrm{M}+2 \mathrm{H}]^{2+}\right)$ and 1,091.3 $\mathrm{Da}\left([\mathrm{M}+\mathrm{H}]^{+}\right)$. The signal peak with a mass of 874.7 Da $\left([\mathrm{M}+4 \mathrm{H}]^{4+}\right)$ determined by MS was the fraction $\mathrm{h}$ in HPLC and matched the sequence of untreated insulin B chain. The investigation of HPLC-MS spectra revealed that there were 5 cleavage sites on the B-chain of insulin at $\mathrm{pH} 6.5$ by wine rennet, including $\mathrm{Gln}^{4}-\mathrm{His}^{5}$, $\mathrm{Ala}^{14}-\mathrm{Leu}^{15}$, Leu ${ }^{15}-\mathrm{Tyr}^{16}$, Tyr ${ }^{16}-\mathrm{Leu}^{17}$, and $\mathrm{Phe}^{24}-\mathrm{Phe}^{25}$ (shown in Figure 4). Because of the higher frequency of peptides starting or ending with $\mathrm{Tyr}^{16}$, Leu ${ }^{17}$, and Leu ${ }^{15}$ compared with that of other peptides, it was suggested that $\mathrm{Tyr}^{16}-\mathrm{Leu}^{17}$ was the susceptible target attacked at $\mathrm{pH} 6.5$, followed by Leu ${ }^{15}-\mathrm{Tyr}^{16}$.

Furthermore, the cleavage specificity of calf and Mucor rennet toward insulin B chain were observed under the same conditions. As shown in Figure 4, wine rennet showed a specificity similar to that of acid proteases from $M$. miehei and $R$. chinensis (Athaudaa and Takahashia, 2002), but different from chymosin. Although the fungal rennet had the same cleavage and preferential sites as wine rennet, about $100 \%$ of insulin $\mathrm{B}$ chain was hydrolyzed (not showed the HPLC results) by Mucor rennet; and the major sites by rhizopuspepsin was $\mathrm{Phe}^{24}-\mathrm{Phe}^{25}$ (Athaudaa and Takahashia, 2002). For chymosin, a large portion of substrate was not degraded, but 3 distinct cleavage sites, $\mathrm{Glu}^{13}-\mathrm{Ala}^{14}$, $\mathrm{Leu}^{15}-\mathrm{Tyr}^{16}$ and $\mathrm{Leu}^{17}-\mathrm{Val}^{18}$, were identified. The cleavage at Leu ${ }^{17}$ $\mathrm{Val}^{18}$ was the major site and not observed for wine or
Mucor rennets. It was noted that the sites of the insulin $B$ chain attacked by the rennets were different from those in previous reports (Garg and Johri, 1994). This may be related to the difference of the $\mathrm{pH}$ used for digestion in this study, which has a marked effect on the cleavage specificity for aspartic protease (Athaudaa and Takahashia, 2002).

\section{Kinetic Properties}

The wine rennet, an exclusive coagulant for Chinese Royal cheese, exhibits caseinolytic activity toward bovine $\kappa$-casein and other casein components (Jiang et al., 2007). However, there are no reliable data about the kinetic properties related to the reaction of wine rennet on caseins. In this paper, the experiments determined the catalytic parameters of wine rennet on the main caseins by gel electrophoresis. The proteolytic fragments are shown in Figure 5, and the profiles of digestion products obtained by chymosin and Mucor rennet were run in parallel. As detected by Gaiaschi et al. (2000, 2001) for proteolytic fragments derived from $\alpha_{\mathrm{S1}^{-}}$and $\beta$-casein, the bands defined as $\alpha_{1}$ and $\beta_{1}$ in Figure 5 corresponded to the $\alpha_{S 1}$-casein fragment $(24-199)$ and the $\beta$-casein fragment (29-209 and 30-209), respectively. The band marked $\kappa_{1}$ was para- $\kappa$-casein (1-105) for chymosin and Mucor rennet (Shammet et al., 1992) or para*-k-casein (1-94) for wine rennet (Jiang et al., 2007). The amount of product associated with bands $\alpha_{1}, \kappa_{1}$, and $\beta_{1}$ at each substrate concentration were determined by densitometry. Figure 6 shows the linear Lineweaver-Burk plots of $1 / v$ against $1 /[\mathrm{S}]$, from which the dynamic parameters were determined and incorporated in Table 2.

As expected, different kinetic behaviors were observed for the 3 proteases on each substrate. With regard to the wine rennet, the $K_{\mathrm{m}}$ was 15 to 22 times higher for $\alpha_{\mathrm{S} 1}$-casein $(0.929 \pm 0.025 \mathrm{mM})$ than for $\beta$-casein and $\kappa$-casein $(0.064 \pm 0.007 \mathrm{mM}$ and $0.043 \pm 0.002 \mathrm{mM}$, respectively), whereas the $\kappa_{\text {cat }} / K_{\mathrm{m}}$ value of $\kappa$-casein $(135.6 \mathrm{mM} / \mathrm{s})$ was about 7 - to 10 -fold greater than that of $\beta$ - and $\alpha_{S 1}$-casein (Table 2). The results suggested 


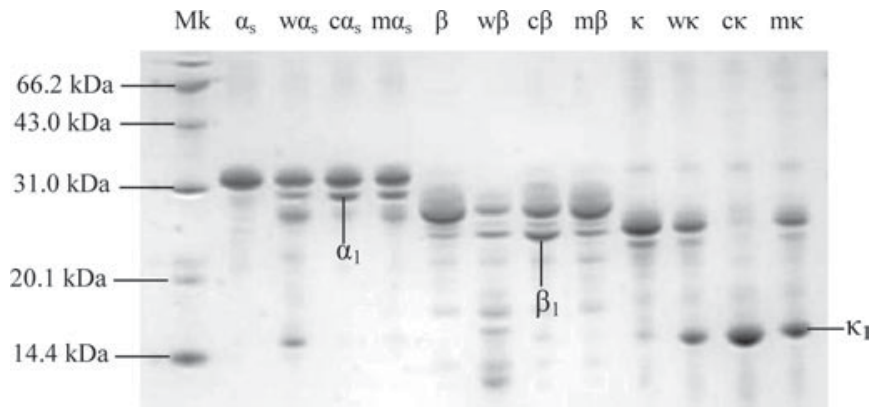

Figure 5. Urea-SDS/PAGE patterns of bovine casein digestion by different rennets at $40^{\circ} \mathrm{C}$ and $\mathrm{pH}$ 6.5. Mk $=$ molecular weight standard; $\alpha_{\mathrm{S}}, \beta, \kappa=\alpha_{\mathrm{S}^{-}}, \beta-$, and $\kappa$-casein; $\mathrm{w}=$ wine rennet; $\mathrm{c}=$ chymosin; $\mathrm{m}$ $=$ Mucor rennet; $\alpha_{1}, \beta_{1}$, and $\kappa_{1}=$ the products derived from $\alpha_{\mathrm{S1}^{-}}, \beta-$, and $\kappa$-casein.

that wine rennet hydrolysis of $\kappa$-casein compared with $\alpha_{S^{-}}$and $\beta$-casein showed a much higher affinity and catalytic efficiency during the initial reaction, which was an important property for rennet at the primary phase of milk clotting (Garg and Johri, 1994). The results in Table 2 indicate similar phenomena for the other 2 enzymes. Consequently, for all bovine caseins, $\kappa$-casein showed an optimum substrate property to the 3 rennets as reflected by the parameter $\kappa_{\text {cat }} / K_{\mathrm{m}}$.

The present studies also revealed some differences in kinetic properties among rennets from wine (Rhizopus species), calf stomach, and M. miehei. The differences between the wine rennet and Mucor rennet were smaller than those between these 2 rennets and calf rennet. Analysis of $K_{\mathrm{m}}$ indicated that the microorganism (Rhizopus and Mucor) enzymes acted preferentially on $\kappa$-casein, followed by $\beta$-casein and finally $\alpha_{S 1}$-casein, whereas the calf rennet acted preferentially on $\kappa$-casein, followed by $\alpha_{\mathrm{S1}^{-}}$-casein and then $\beta$-casein. Results in Table 2 show that $\kappa_{\text {cat }}$ (and thus $V_{\max }$ ) of chymosin on $\kappa$-casein was almost 2-fold greater than that of Mucor rennet and almost 6-fold greater than that of wine rennet. Nevertheless, calf chymosin had a similar proteolytic coefficient $\left(\kappa_{\text {cat }} / K_{\mathrm{m}}\right)$ to the latter 2 rennets because of a higher $K_{\mathrm{m}}$ value. In the case of $\beta$-casein, the kinetic parameters (except the $K_{\mathrm{m}}$ of wine rennet) on the $\mathrm{Lys}^{28}$-Lys ${ }^{29}$ bond were of the same order of magnitude for the 3 enzymes in this study, although the $K_{\mathrm{m}}$ for wine rennet was about 4.3 and 2.7 times lower than that for chymosin and Mucor rennet, respectively (Table 2 ). For $\alpha_{\mathrm{S1}}$-casein, wine rennet had a higher $\kappa_{\text {cat }}$ value, which indicated that wine rennet should enhance the proteolysis of $\alpha_{\mathrm{S} 1}$-casein during the enzymatic phase of cheese making, although it had lower affinity as implied by higher values of $K_{\mathrm{m}}$; all rennets exhibited almost the same $\kappa_{\text {cat }} / K_{\mathrm{m}}$ values. Moreover, the urea-PAGE profiles of the hydrolysis of $\alpha_{S_{1}-}$ and $\beta$-casein by wine rennet showed several other fragments
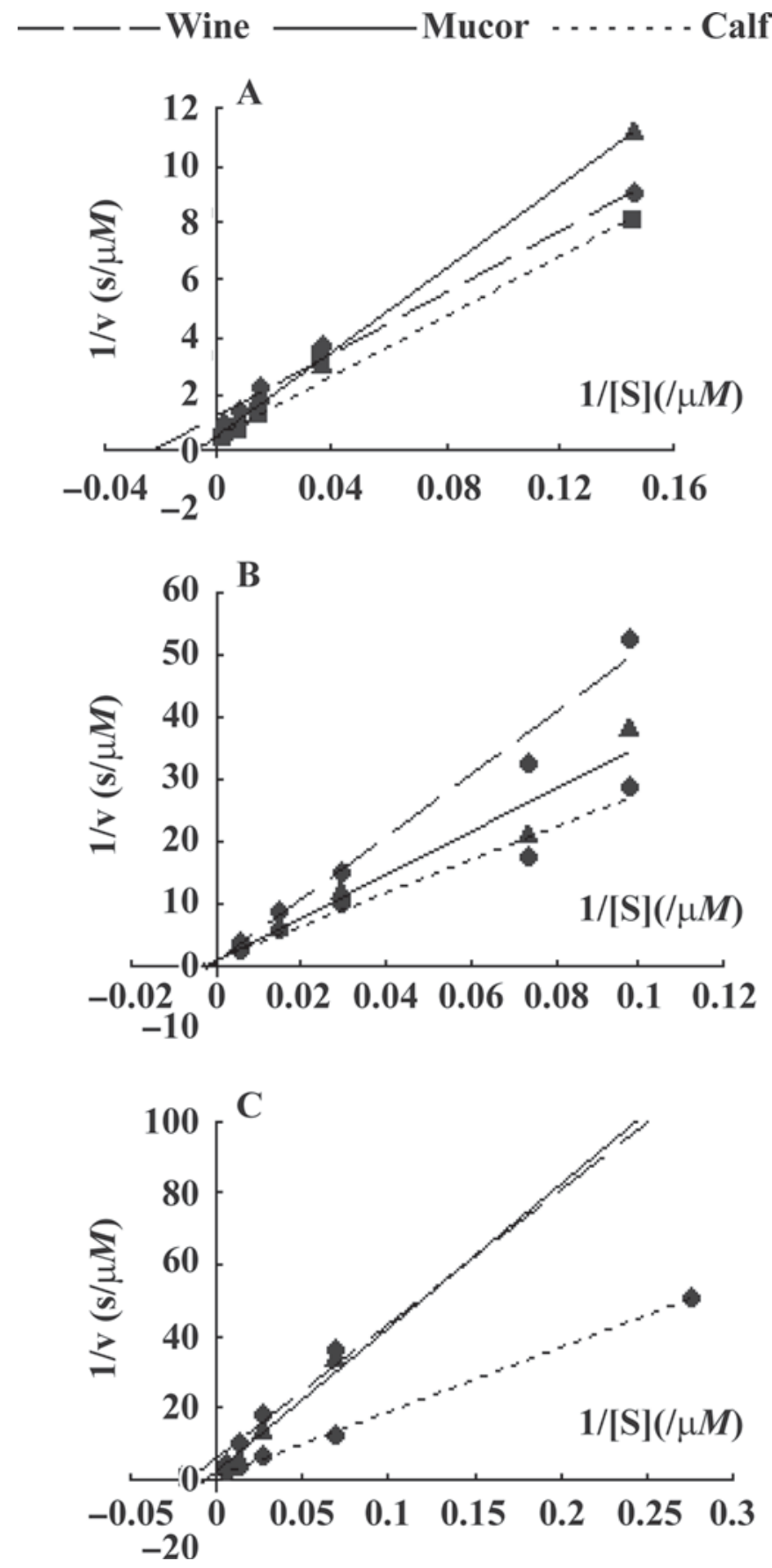

Figure 6. Lineweaver-Burk plots for the cleavage of $\kappa$-casein (A), $\alpha_{\mathrm{S} 1}$-casein (B), and $\beta$-casein (C) by wine, calf, and Mucor rennets at pH 6.5 and $40^{\circ} \mathrm{C} . v=$ initial rate; $[\mathrm{S}]=$ substrate concentration.

that cannot be observed in digestions by calf rennet or Mucor rennet (Figure 5). Overall, the wine rennet exhibited significant milk-clotting activity on $\kappa$-casein and caseinolytic activity on $\alpha_{\mathrm{S1}^{-}}$and $\beta$-caseins.

It was noted that the kinetic parameters for chymosin on $\kappa$ - and $\alpha_{S_{1}}$-caseins in this study were different from those found previously (Hill et al., 1974; Carles 
and Martin, 1985; Carles and Ribadeau Dumas, 1985; Vreeman et al., 1986). This fact was mainly related to the difference of substrate and the content of active enzyme. The heterogeneity of bovine caseins has a certain extent of influence on kinetics of the reaction (Vreeman et al., 1986). For א-casein, in addition to the amino acid replacements, the amounts of carbohydrate and phosphate group were different in each genetic variant. The characterization of bovine caseins employed in present experiment was not determined. The isolated $\kappa$-casein mainly exists in solutions with an $M_{\mathrm{r}}$ of 600,000 (30 monomers) and a diameter of $23 \mathrm{~nm}$, whereas at low concentrations $(<25 \mu M)$, only monomers $\left(M_{\mathrm{r}} 19,000\right)$ are present. The wide difference in size of $\kappa$-casein particle could influence the kinetic parameters (Vreeman et al., 1986). Under our working conditions, $\kappa$-casein concentrations were lower compared with those employed in previous studies (Hill et al., 1974; Carles and Martin, 1985; Carles and Ribadeau Dumas, 1985). The enzyme concentrations used to calculate the initial velocity of the reaction of wine rennet on bovine caseins in this paper were the content of whole protein, not of the active enzyme. Therefore, different results were obtained from our experiment.

\section{CONCLUSIONS}

In summary, wine rennet is a monomeric and nonglycosylated acid protease produced by molds of the genus Rhizopus. The HPLC-mass spectra revealed that wine rennet resulted in 2 major split bonds, $\mathrm{Tyr}^{16}-\mathrm{Leu}^{17}$ and $\mathrm{Leu}^{15}-\mathrm{Tyr}^{16}$, and 3 other cleavage sites, Gln ${ }^{4}-\mathrm{His}^{5}, \mathrm{Ala}^{14}$ $\mathrm{Leu}^{15}$, and $\mathrm{Phe}^{24}-\mathrm{Phe}^{25}$ on the insulin $\mathrm{B}$ chain at $\mathrm{pH}$ 6.5 , which was different from calf chymosin under the same conditions. The results of kinetics showed that the 3 studied rennets had a similar coagulant efficiency, reflected by the proteolytic coefficient for $\kappa$-casein, but the reaction rates were distinct from each other. The catalytic characterization of wine rennet showed a higher caseinolytic activity on $\alpha_{\mathrm{S}^{-}}$and $\beta$-casein than the Mucor enzyme. In other words, wine rennet purified from glutinous rice wine showed significant milk-clotting ability and caseinolytic activity; therefore, it would be a good assistant for calf rennet or as an accelerator used in the process of cheese making.

\section{ACKNOWLEDGMENTS}

We thank Wang Yunhai (Beijing University of Technology) for his help in performing HPLC-MS spectra and anonymous reviewers for their insightful comments. This work was funded by the Research and Development Program of China (2006BAD04013) from the National Department of Science and Technology. 


\section{REFERENCES}

Aikawa, J., T. Yamashita, M. Nishiyama, S. Horinouchi, and T. Beppu. 1990. Effects of glycosylation on the secretion and enzyme activity of Mucor rennin, an aspartic proteinase of Mucor pusillus, produced by recombinant yeast. J. Biol. Chem. 265:13955-13959.

Andrews, A. T. 1983. Proteinases in normal bovine milk and their action on caseins. J. Dairy Res. 50:45-55.

Athaudaa, S. B., and K. Takahashia. 2002. Cleavage specificities of aspartic proteinases towards oxidized insulin B chain at different $\mathrm{pH}$ values. Protein Pept. Lett. 9:289-294.

Azarnia, S., N. Robert, and B. Lee. 2006. Biotechnological methods to accelerate cheddar cheese ripening. Crit. Rev. Biotechnol. $26: 121-143$.

Barkholt, V. 1987. Amino acid sequence of endothiapepsin. Complete primary structure of the aspartic protease from Endothia parasitica. Eur. J. Biochem. 167:327-338.

Carles, C., and P. Martin. 1985. Kinetic study of the action of bovine chymosin and pepsin on bovine $\kappa$-casein. Arch. Biochem. Biophys. 242:411-416.

Carles, C., and B. Ribadeau Dumas. 1985. Kinetics of the action of chymosin (rennin) on a peptide bond of bovine $\alpha_{s 1}$-casein. Comparison of the behavior of this substrate with that of $\beta$ - and К-caseins. FEBS Lett. 185:282-286.

Costa, J., D. A. Ashford, M. Nimtz, I. Bento, C. Frazao, C. L. Estevez, C. J. Faro, J. Kervinen, E. Pires, P. Verissimo, A. Wlodawer, and M. A. Carrondo. 1997. The glycosylation of the aspartic proteinases from barley (Hordeum vulgare L.) and cardoon (Cynara cardunculus L.). Eur. J. Biochem. 243:695-700.

Gaiaschi, A., B. Beretta, C. Poiesi, A. Conti, M. G. Giuffrida, C. L. Galli, and P. Restani. 2000. Proteolysis of $\alpha_{S^{-}}$casein as a marker of Grana Padano cheese ripening. J. Dairy Sci. 83:2733-2739.

Gaiaschi, A., B. Beretta, C. Poiesi, A. Conti, M. G. Giuffrida, C. L. Galli, and P. Restani. 2001. Proteolysis of $\beta$-casein as a marker of Grana Padano cheese ripening. J. Dairy Sci. 84:60-65.

Garg, S. K., and B. N. Johri. 1994. Rennet: Current trends and future research. Food Rev. Int. 10:313-355.

Hidaka, M., K. Sasaki, T. Uozumi, and T. Beppu. 1986. Cloning and structural analysis of the calf prochymosin gene. Gene 43:197203.

Hill, R. D., E. Lahav, and D. Givol. 1974. A rennin-sensitive bond in alpha-s1 B-casein. J. Dairy Res. 41:147-153.

Jiang, T., L. J. Chen, L. Xue, and L. S. Chen. 2007. Study on milkclotting mechanism of rennet-like enzyme from glutinous rice wine:
Proteolytic property and the cleavage site on k-casein. J. Dairy Sci. 90:3126-3133.

Jiang, T. M., L. Xue, W. M. Zhou, and L. J. Chen. 2006. Purification and preliminary discussion on coagulation mechanism of rennet from glutinous rice wine. Food Ferment. Ind. 32:24-27.

Liu, Z. M., H. Liu, and C. X. Lao. 2001. Studies on the screening of rennet producing strain and its culture conditions. Food Ferment. Ind. 27:8-11.

Machalinski, C, M. L. Pirpignani, C. Marino, A. Mantegazza, an M. B. de Jiménez Bonino. 2006. Structural aspects of the Mucor bacilliformis proteinase, a new member of the aspartyl-proteinase family. J. Biotechnol. 123:443-452.

Poza, M., M. Prieto-Alcedo, C. Sieiro, and T. G. Villa. 2004. Cloning and expression of clt genes encoding milk-clotting protease from Myxococcus xanthus 422. Appl. Environ. Microbiol. 70:63376341.

Rickert, W. S., and P. A. McBride-Warren. 1974. Structural and functional determinants of Mucor miehei protease. Biochim. Biophys. Acta 336:437-444.

Shammet, K. M., R. J. Brown, and D. J. McMahon. 1992. Proteolytic activity of some milk-clotting enzymes on $\kappa$-casein. J. Dairy Sci. $75: 1373-1379$.

Takahashi, K. 1988. Determination of the amino acid sequences of the two major isozymes of rhizopuspepsin. J. Biochem. 103:162-167.

Teng, G. X. 2005. Characteristics of Rhizopus milk-clotting enzyme in jiu-yao and studies on texture of kou wan lao. $\mathrm{PhD}$ thesis. China Agric. Univ., Beijing.

Visser, S., and H. S. Rollema. 1986. Quantification of chymosin action on nonlabeled kappa-casein-related peptide substrates by ultraviolet spectrophotometry: description of kinetics by the analysis of progress curves. Anal. Biochem. 153:235-241.

Visser, S., P. J. Van Rooijen, and C. J. Slangen. 1980. Peptide substrates for chymosin (rennin) Isolation and substrate behaviour of two tryptic fragments of bovine $\kappa$-casein. Eur. J. Biochem. 108:415-421.

Vreeman, H. J., S. Visser, C. J. Slangen, and J. A. Van Riel. 1986 Characterization of bovine $\kappa$-casein fractions and the kinetics of chymosin-induced macropeptiede release from carbohydratefree and carbohydrate-containing fractins determined by highperformance gel-permeation chromatography. Biochem. J. 240:87-97.

Xue, L., L. J. Chen, T. M. Jiang, and W. M. Zhou. 2008. Study on properties of chymosin purified from glutinous rice wine. Food Sci. 29:259-262. 